\title{
Penerapan Konsep Warna Dingin Pada Tata Artistik Program Televisi Dunia Anak TVRI Bali
}

\author{
Ni Kadek Wina Ferninaindis ${ }^{1}$, Hendra Santosa ${ }^{2}$, I Komang Arba Wirawan ${ }^{3}$ \\ ${ }^{1}$ Program Studi Pengkajian Seni (S2) \\ ${ }^{2}$ Program Studi Seni Karawitan \\ ${ }^{3}$ Program Studi Film dan Televisi \\ Institut Seni Indonesia Denpasar \\ Jalan Nusa Indah Denpasar Bali \\ 33hendrasnts@gmail.com
}

Warna merupakan hal penting dalam memperindah tata artistik sebuah program acara televisi. Pengaplikasian warna juga menjadi hal yang yang patut menjadi perhatian dalam menambah mood pengisi acara didalamnya. Warna dingin sebagai warna dasar dari program Tata Artistik Dunia Anak TVRI Bali telah mengaplikasikan hal tersebut. Warna dingin merupakan warna yang memberikan kesan dingin, menyenangkan, menyejukan, dan kenyamanan di dalam sebuah ruangan. Metode yang digunakan adalah metode deskriptif kualitatif. Artikel ini bertujuan untuk mengkaji pengaruh warna dingin terhadap sebuah tata artistik program Dunia Anak TVRI Bali yang merupakan program khusus untuk anak-anak yang sedang dalam masa pertumbuhan. Untuk mendukung hal tersebut, warna yang diterapkan pada tata artistiknya adalah warna yang bersahabat dengan penglihatan anak. Oleh karenanya pemilihan warna dingin merupakan warna yang sangat sesuai untuk dipergunakan sebagai warna utama dari penataan artistik untuk program anak-anak. Hal ini disebabkan oleh karena pengaruh warna dingin dapat memberikan pengaruh sangat besar bagi psikologi anak dalam menumbuhkan kreatifitas serja imajinasi anak itu sendiri.

\section{Kata Kunci : Warna Dingin, Tata Artistik, Dunia Anak TVRI Bali.}

Color is important in beautifying the artistic order of a television program. the application of color is also something that deserves attention in adding to the mood of the performers in it. Cold color as the basic color of the Children's World Artistic Tata TVRI Bali program has applied it. Cold color is a color that gives the impression of cold, pleasant, soothing, and comfort in a room. The method used is the descriptive qualitative method. This article aims to examine the effect of cold colors on an artistic arrangement of the Dunia Anak TVRI Bali program which is a special program for children who are in their infancy. To support this, the colors applied to the artistic system are colors that are friendly to the child's vision. Therefore the selection of cold colors is a color that is very suitable to be used as the main color of the artistic arrangement for children's programs. This is due to the influence of cold colors can provide a very large influence on the psychology of children in growing creativity and imagination of the child.

Keyword : Cold Colour, Artistic Arragement, Dunia Anak TVRI Program

Proses Review : 1 - 28 Januari 2020, Dinyatakan Lolos: 10 Februari 2020 


\section{PENDAHULUAN}

Sebelumnya penulis ucapkan terima kasih kepada Ristekdikti dengan kontrak nomor 003/SP2H/LT/DRPM/2019 yang telah memberikan pendanaan pada penelitian kami yang berjudul "Kesetaraan Gender Dan Tata Artistik Sebagai Tema Penciptaan Dan Penelitian Pertelevisian". Artikel merupakan salah satu luaran dari dua luaran wajib penelitian payung Tesis Magister. Artikel sebelumnya berjudul: "Actualization Of Women In Domestic Areas In The Galuh Film" (Aryawaningrat, 2019) yang diterbitkan oleh jurnal Capture ISI Surakarta.

Televisi merupakan sebuah media komunikasi yang berfungsi sebagai penerima siaran gambar bergerak berserta suara, baik itu hitam-putih ataupun berwarna. Televisi berasal dari kata Yunani, yakni tele dan visio, sehingga dapat diartikan sebagai alat komunikasi jarak jauh yang menggunakan media visual/atau pengelihatan. Seiring berjalannya waktu televisi semakin berkembang dengan hadirnya berbagai macam program siaran yang menghibur, baik itu dengan konten berita yang sedang buming, maupun aara hiburan yang terbagi dalam berbagai kategori, mulai dari kategori anak-anak hingga dewasa. Program siaran didefinisikan sebagai satu bagian atau segmen dari radio maupun televisi secara keseluruhan, sehingga memberikan pengertian bahwa dalam siaran keseluruhan terdapat beberapa program yang diudarakan (Andi, 2011).

Lantas bagaimana sebuah stasiun televisi itu mengkemas program acara yang disiarkan menjadi menarik bagi penonton, terkhusus bagi penonton yang masuk dalam kategori anak-anak ?

TVRI Bali menayangkan sebuah program Dunia Anak yang dikategorikan untuk anak-anak, selain menghibur dalam program ini juga menyisipkan segmen edukasi yang bermanfaat bagi anak-anak. Untuk mengkemas program ini menjadi menarik dan tentunya bersahabat bagi anak-anak, devisi artistik haruslah memiliki kreatifitas yang tinggi untuk menghadirkan suasana ruangan yang menyenangkan, selain dari properti, warna pun sangat menentukan keceriaan anak-anak selama mengikuti maupun menontonnya melalui layar kaca televisi. Setiap warna memiliki karakteristik, karakteristik yang dimaksud disini adalah ciri-ciri atau sifat khas yang dimiliki oleh suatu warna. Sifat khas yang dimiliki oleh warna ada dua golongan besar, yakni warna panas dan warna dingin (Maruta, 2019; Sulasmi, 2011)

Warna sering digunakan sebagai penarik perhatian yang kerap kali dimanfaatkan sebagai media promosi bagi kepentingan periklanan sebuah produk, ataupun media promosi untuk sebuah tayangan televisi. Dalam teori wana terdapat beberapa warna dasar yang terdiri dari warna merah, kuning dan biru yang disebut dengan warna premier. Selain itu pula dalam teori warna juga dikenal den- gan istilah warna sekunder, tersier, monokrom, warna analog, kontras dan komplementer. Warna-warna inilah yang seing digunakan atau diaplikasikan untuk kepentingan media promosi iklan, atau penerapan warna pada sebuah program televisi dengan tujuan memenuhi "look" yang diinginkan.

Berdasarkan pengamatan peneliti, warna yang dominan dipalikasikan kedalam tata artistik program Dunia anak adalah warna hijau. Karaktertistik warna hijau masuk kedalam golongan warna dingin atau sejuk. Dipilihnya warna hijau sebagai warna dasar dari penataan artistik Dunia Anak TVRI Bali karena warna yang berkarakter sejuk ini dirasa mampu mempengaruhi emosional anakanak, ditambah lagi kegiatan ini dilakukan didalam ruangan, maka suasana ruangan pun harus bersahabat dengan anak-anak. Agar dapat memenuhi rasa bebas dalam ruangan, anak-anak selaku pengisi acara memerlukan suasana ruangan yang fleksibel dengan didukung oleh warna yang netral (Mita Purbasari, 2014). Untuk memenuhi kebutuhan anak akan rasa aman dalam ruangan shoting, warna yang diaplikasikan sebaikanya tidak menakutkan dan menegangkan.

\section{METODE}

Penulisan artikel ini menggunakan metode kualitatif. Secara garis besar, langkah-langkah dalam melaksanakan penelitian ini beberapa tahapan yaitu: Tahap pengumpulan data, yaitu mengenai segala sesuatu yang berkaitan dengan objek yang akan di teliti. Adapun tahapan-tahapan, melakukan studi pustaka, pendokumentasian, observasi, serta wawancara. Pada tahap wawancara peneliti memberikan pertanyaan mengenai pemilihan warna, serta alasan penggunakan warna tersebut sebagai warna dasar dari penataan tata artistik Dunia Anak TVRI Bali, serta pengaruh warna tersebut bagi psikologi anak, pertanyaan ini diberikan kepada art director selaku pemimpin tim guna mendapatkan data lisan mengenai warna yang kemudian dijadikan dasar dari pembahasan pada penelitian ini.

Kemudian peneliti melanjutkan dengan menggunakan metode observasi, yakni mengamati cara-cara para tim tata artistik bekerja membuat set yang sesuai dengan tema yakni anak-anak. Tujuan dilakukannya observasi atau pengamatan langsung adalah agar peneliti bisa mengatahui tahapan-tahapan yang dilalui oleh para tim untuk bisa menciptakan sebuah set yang sudah ditentukan, dan untuk mengetahui apakah para tim artisitik di TVRI Bali sudah menerapkan ketentuan-ketentuan yang ada sebagai seorang penata artisitk. Setelah observasi selesai, penulis kemudian melakukan studi pustaka sebagai landasan untuk mengkaji warna dingin sebagai warna utama yang diaplikasikan kedalam program Dunia Anak TVRI Bali.

Selain observasi langsung peneliti juga menjadikan video tayangan Dunia Anak TVRI Bali yang diunduh melalui 
laman youtube sebagai data utuh dari program tersebut, mulai dari konten acara, set keseluruhan, properti dan warna dapat diperoleh melalui video, sehingga peneliti dapat mengamati tone warna yang diaplikasikan melalui media video dan melihat perubahan look warna dari pengamatan langsung langsung dan pengamatan melalui video. Video yang digunakan sebagai refrensi dlah video Dunia Anak dengan pengisi acara dari siswa/siswi dari SD N 1 Kawan Bangli yang tayang pada tanggal 1 Juni 2018 dan tanggal 7 Desember 2018. Video kedua adalah video Dunia Anak dengan pengisi acara dari SD Cipta Dharma Denpasar yang tayang pada tangga 6 Juni 2018 dan 2 November 2018. Kedua video ini dibagi menjadi dua paket yang berbeda tentunya dengan tema yag berbeda, namun dengan pengisi acara yang sama yakni dari SD N 1 Kawan Bangli dan SD Cipta Dharma Denpasar.

Tahap analisis dan pengolahan data, yaitu menganalisa atau mengkaji objek melalui data-data yang diperoleh sesuai dengan pembahasan. Pada tahap ini, peneliti memfokuskan pembahasan terhadap fungsi warna bagi ruangan, dan pengaruh warna bagi anak-anak, yang kemudian di cocokan dengan sumber pustaka yang membahas secara lengkap mengenai warna dan karakteristik dari setiap warna. Tahap inilah peneliti akan menganalisis setiap warna yang diaplikasikan pada program Dunia Anak TVRI Bali, dan tujuan dari pemilihan warna tersebut sebagai salah satu unsur tata artistik program tersebut.

Tahap penyusunan karya tulis, yaitu tahapan terakhir dalam penulisan karya tulis ini disusun secara baik. Pada tahap ini merupakan tahap final dari penelitian, yang mana setiap pembahasan sudah dikaji sesuai dengan tema penelitian dan tentunya sudah didukung dengan sumber-sumber yang mendukung.

\section{HASIL DAN PEMBAHASAN}

\section{Kajian Pustaka}

Dalam mengkaji konsep warna dingin pada tata artistik program Dunia Anak yang disiarkan oleh TVRI Bali menggunakan materi yang berkaitan dengan produksi sebuah tayangan televisi, pengertian serta pengaruh warna bagi psikologi anak. Langkah awal yang dilakukan adalah melalui riset pustaka sebagai pertanggung jawaban ilmiah pada kajian ini. Adapun sumber rujukan tertulis dalam penulisan artikel ini adalah sebagai berikut

“Andi Fachruddin. 2011. Dasar-dasar Penyiaran : Sejarah, Organisasi, Operasional, dan Regulasi. Penerbit Kencana Prenada Group, Jakarta". Dalam buku ini membahas mengenai sejarah perkembangan penyiaran di dunia dan juga membahas format acara atau bisa dikatakan juga bentuk acara serta membahas kategori acara yang akan disiarkan. "Sulasmi Darmaprawira W.A. WARNA: Teori dan Kreativitas Penggunaanya. Penerbit ITB,Bandung. Buku ini membahas mengenai karakteristik warna dan kegunaann- ya dalam setiap pengaplikasiannya sesuai dengan kebutuhan ruang.

"Sriti Mayang Sari. Peran Warna Interior Terhadap Perkembangan Dan Pendidikan Anak di Taman KanakKanak. Jurnal Dimensi Interior, Vol.2 No.1 Juni 2004. Universitas Kristen Petra". Dalam jurnal ini membahas mengenai pentingnya peran warna dalam menstimulasi anak-anak untuk mendapatkan rasa nyaman saat berada di dalam ruangan.

"Monica Laura Christian Luzar. Efek Warna Dalam Desain Dan Periklanan". Jurnal Humaniora Vol.2, No.2 Oktober 2011. Jurnal ini membahas lebih dalam mengenai warna dingin, dan penempatannya sesuai dengan kebutuhan ruangan maupun produk.

'Mita Purbasari, R.A Diah Resita I. K. Jakti. Warna Dingin Si Pemberi Nyaman. Jurnal Humaniora, Volume 5 No.1 April 2014." Jurnal ini membahas lebih dalam mengenai warna dingin, dan penempatannya sesuai dengan kebutuhan ruangan maupun produk.

"RM. Bambang Setyohadi KP. Pengaruh Warna Terhadap Kamar Tidur Anak. Jurnal Teknik Sipil \& Perencanaan, Vol.12, No.1, Januari 2010. Jurnal membahasa mengenai pengaruh waran bagi anak-anak yang terfokus pada perancangan kamar tidur atau ruangan, agar ruangan dapat menjadi ruangan yang nyaman khususnya bagi anak-anak.

\section{Progran Dunia Anak TVRI Bali}

Program Dunia Anak TVRi Bali sebuah program yang memfokuskan tayangan pada edukasi anak serta menampilkan bakat yang dimiliki oleh anak-anak. Program ini bekerjasama dengan beberapa sekolah dasar di Denpasar khususnya sebagai pengisi acara disetiap episodenya. Setiap episode yang tayangkan oleh Dunia Anak memiliki tema yang berbeda, tema yang paling sering disiarkan yakni tema pendidikan contohnya science experiment, mesatua Bali (bercerita dengan menggunakan bahasa Bali) dan kegiatan kreativitas seperti berpuisi, menari, menyanyi dan kegiatan kretifas lainnya yang kerap dilakukan disekolah. Program Dunia Anak juga merupakan sebuah wadah acara untuk anak-anak yang melibatkan anak-anak pada usia dasar. Anak-anak yang terlibat juga merupakan anak-anak yang memiliki potensi atau bakat dan prestasi dibidang akademik maupun non akademik. Bentuk acara dari program ini adalah program variety show atau dikenal dengan program hiburan, yang isi dari program hiburan ini adalah edukasi.

Program Dunia Anak ini dikemas dengan bentuk acara hiburan beredukasi. Untuk menghasilkan program yang menghibur serta mengedukasi, memerlukan proses yang cukup panjang ditambah lagi melibatkan anak-anak kurang lebih sekitar 50-60 anak sebagai pengisi acara pada program tersebut. Selain melibatkan anak-anak sebagai 


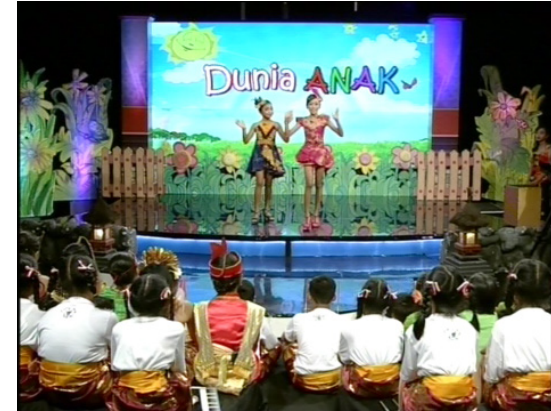

Gambar 1. Segment 1 Menit 2:46 Program Dunia Anak TVRI Bali

(Sumber : LPP TVRI Bali, tahun 2018)

pengisi acara, Pprogram ini bekerjasama dengan sekolah dan sangar Se-Bali untuk dapat tampil pada setiap episode program Dunia Anak. Produser selaku pemimpin dari program ini harus melalui tahap seleksi untuk pengisi acara, karena pada dasarnya program ini adalah hiburan maka yang harus mengisi program Dunia Anak haruslah pengisi acara yang siap tampil dan tentunya mampu menghibur penonton.

Tayangan Dunia Anak bukan merupakan program hiburan yang komersil melainkan program layanan publik untuk mengedukasi masyarakat dan penonton. Seperti fungsinya to educate, TVRI Bali menerapkan fungsi tersebut sebagai sebuah lembaga siaran lokal berbasis layanan publik, maka setiap tayangannya tidak sepenuhnya diisi oleh artis-artis lokal Bali yang sudah terkenal melainkan melibatkan sanggar, sekolah dan seniman-seniman yang berprestasi dibidangnya masing-masing.

Program Dunia Anak TVRI Bali memilih tema luar ruangan dalam proses perekaman yang dilakukan didalam studio. Studio di kondisikan sebagaimana sedang berada pada sebuah taman yang ceria dan bersahabat dengan anak-anak. Selain properti pendukung, warna yang diaplikasikan pun cenderung memiliki karakteristik warna dingin yang tentunya menambah keceriaan anak-anak dalam melaksakan proses shoting. Segala ketentuan set pada program ini tidak terlepas juga dari peran produser sebagai pemimpin program untuk mengawasi serta memberikan refrensi kepada art director untuk memproduksi tata artistik pada program Dunia Anak. Tata artisitk program ini memiliki dua penataan artistik, yang pertama properti general dan properti sesuai dengan tema yang berbeda pada setiap episodenya. Properti general merupakan properti utama yang menjadi wajah dari program dunia anak, yang mana properti ini tidak mengalami perubahan yang signifikat disetiap episodenya, properti juga menjadi ciri khas dari program dunia anak TVRI Bali, sedangkan properti yang disesuaikan dengan tema adalah properti yang dibeuat sesuai kebutuhan atau tema yang sudah ditentukan sebelumnya, dengan tujuan menghidupkan suasana.

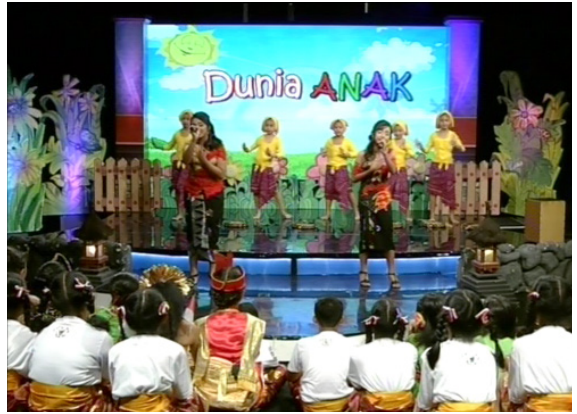

Gambar 2. Segmen 1 Program Dunia Anak TVRI Bali (Sumber: LPP TVRI Bali, Tahun 2018)

Video yang menjadi acuan untuk dianalisis warna pada tata artistiknya adalah video program Dunia Anak yang tayang pada tahun 2018 dengan tema Bhineka Tunggal Ika yang mana pengisi acara program tersebut berasal dari SD Negeri 1 Kawan Bangli.

Berdasarkan gambar 1 diatas yang diambil dengan angle long shot, dapat terlihat dengan jelas kondisi studio secara keseluruhan. Penggunaan properti yang menambah suasana ceria, dan panggung yang yang dihias secara baik bertujuan memberi kesan nyaman bagi anak-anak selaku pengisi acara. Seperti yang telah dibahas sebelumnya, pengaplikasian warna yang dominan adalah warna dingin, maka pada layar LED sebagai pengganti properti umum dari program Dunia Anak diaplikasikan warna biru yang cenderung lebih banyak, dapat dilihat pula properti tambahan seperti pagar buatan, bunga buatan juga diletakkan diantara panggung.

Pada segmen satu pada gambar 2 diatas, pengisi acara sudah mulai menamplkan bakat yang dimiliki. Secara keseluruhan set tidak berubah sama sekali dari segmen awal, yang berubah hanyalah pengisi acaranya saja. Wardrobe yang dikenakan oleh pengisi acara pun menyatu dengan set sehingga look dari program tersebut dapat menarikperhatian. anak-anak distudio maupun dirumah.

Selanjutnya akan diberikan contoh dari pengisi cara SD Cipta Dharma Denpasar, yang mana temayang akan ditampilkan tentu saja berbeda dari SD sebelumnya,

Pada gambar 3 terlihat perbedaan dari set sebelumnya. Pada set ini yang berkurang adalah pagar buatan yang diganti dengan lampu rotan yang berda diantara penonton. Dari segi warna keseluruhan set tidak mengalami perubahan yang signifikan, yang menarik pada episode ini adalah wardrobe yang dikenakan oleh para pengisi acara, terlihat wardrobe yang dikenakan merupakan busana daerah dari berbagai suku yang ada di Indonesia, ada juga wardrobe yang merupakan busana masa sekarang yang modis dan 


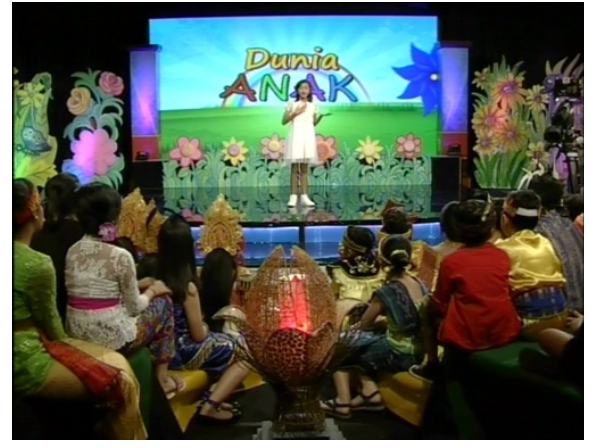

Gambar 3. Segmen 1 Dunia Anak SD Cipta Dharma (Sumber : LPP TVRI Bali, thn 2018)

trendi, tentunya sesuai dengan umur anak-anak.

Tema yang kerap kali memerlukan properti yang cukup rumit adalah tema tradisional klasik, yang mana dari segi bentuk dan warna pun haruslah klasik, dengan warna coklat yang lebih mendominasi, meski begitu properti general tetap mewakili dunia anak yang ceria, dengan pengaplikasian warna dingin seperti ungu, hijau, dan biru yang masih mendominasi warna pada penataan artistik Dunia Anak TVRI Bali. Program Dunia Anak TVRI Bali tayang setiap hari Minggu, sesuai jadwal tayang yang sudah disusun sebelumnya. Dalam sebulan program ini tayang satu kali, dikarenakan membutuhkan waktu ekstrabagi para kru dan pengisi acara untuk mempersiapkan segala sesuatu sehingga tayangan inidapat menjadi program siap tayang. Program Dunia Anak TVRI Bali merupakan tayangan yang tidak disiarkan secara live, melainkan tayangan rekaman yang mana proses penayangannya akan direkam terlebih dahulu selayaknya tayangan live, yang kemudian direkam dan diedit sesuai dengan kebutuhan penayangan TVRI Bali dan juga meminimalisir kesalahan ucap oleh para pengisi acara mengingat pengisi acara dan target tayangnya adalah anak-anak. Proses rekaman program ini merupakan program paket, yang mana paket tersebut merupakan pengisi acara yang sama namun dengan tema yang berbeda. Setiap pengisi acara diberi waktu 1 bulan untuk latihan oleh produser, sehingga pada saat proses rekaman anak-anak sebagai pengisi acara sudah siap tampil tanpa ada pengarahan yang cukup banyak.

Pada program Dunia Anak TVRI Bali tidak hanya terdiri dari konsep acara yang sesuai dengan anak, dan pengisi acara yang berbakat, program ini juga didukung oleh penataan artistik yang sangat sesuai dengan anak-anak, mulai dari properti, set dan wardrobe, warna pun menjadi salah satu unsur yang sangat penting karena warna akan mempengaruhi mood anak-anak selama proses rekaman berlangsung. Warna yang dipilih oleh tim tata artistik dominan warna dingin. Pada pembahasan selanjutnya akan diuaraikan konsep warna dingin pada program Dunia Anak TVRI Bali serta pengaplikasianya pada tata artistik program Duna Anak.

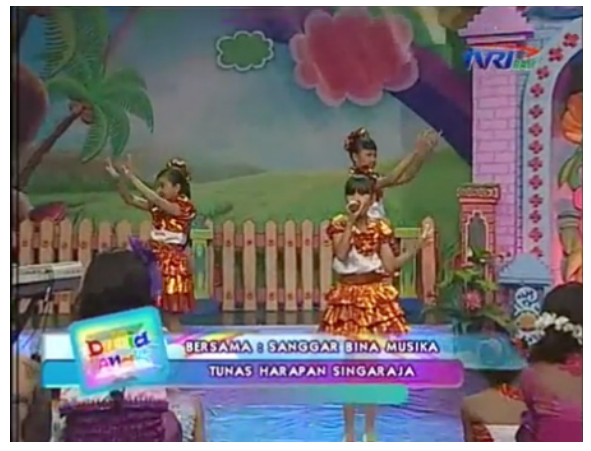

Gambar 4. Tata Artistik Dunia Anak TVRI Bali Sumber : (Vina, 2016) (youtube, diunduh 13 Mei 2019, pukul 14.00 wita)

Konsep Warna Dingin

Konsep warna di Bali terdapat dalam konsep Pengider Buana Dewata Nawa Sanga.

Karakter masing-masing Dewata Nawa Sanga dan simbol-simbol yang terungkap lewat bentuk figur maupun atribut-atribut yang menyertainya, memiliki identitas tersendiri sesuai dengan kedudukan Dewata Nawa Sanga. Karakter ekspresi masing-masing wajah Dewata Nawa Sanga lebih banyak dijadikan acuan dalam proses penciptaan seni lukis masih bersifat klasik, tradisional, dan dekoratif sesuai dengan lingkungan daerah serta situasi kondisi dimana penggunaan konsep Dewata Nawa Sanga itu dipergunakan (Wirakesuma, 2017). Namun dalam artikel ini konsep warna ini tidak dipergunakan, tetapi menggunakan konsep warna dingin.

Penataan sebuah tata artistik selain harus memperhatikan konten serta properti yang nantinya akan diaplikasikan sebagai pelengkap maupun pendukung dari sebuah program acara, warna pun menjadi salah satu elemen yang dirasa sangat berpengaruh bagi pengelihatan serta perasaan penonton maupun pengisi acara pada tayangan tersebut. Penggunaan warna untuk penataan ruang tidak terlepas dari fungsi dari ruangan tersebut, tujuan pewarnaan ruang tidak terbatas hanya sekedar menyenangkan mata saja, melainkan mempunyai tujuan lain, contohnya saja peningkatan efiseinsi kerja, penyembuhan dan mengundang selera. Untuk memenuhi rasa bebas dalam ruang, anak memerlukan suasana ruang yang fleksibel, tidak terlalu padat dan didukung dengan warna terang dan warna netral, karena skema warna netral adalah yang paling fleksibel (Ching, 1996)

Penting untuk dipahami bahwa seorang anak belum mempunyai persepsi yang utuh menganai ruangan, anak mengamati detail-detail dari bagian ruangan yang disenangi, mulai dari furnitur, warna-warna pada dinding, atau unsur ruangan lainnya (Sriti, 2004). Sama halnya dengan penataan artistik pada program Dunia Anak yang disiarkan oleh TVRI Bali, dengan mengusung tema anak-anak, maka setiap unsur dalam tata artistik tersebut haruslah berhubungan dengan anak-anak, dan setiap unsurnya pun harus ber- 


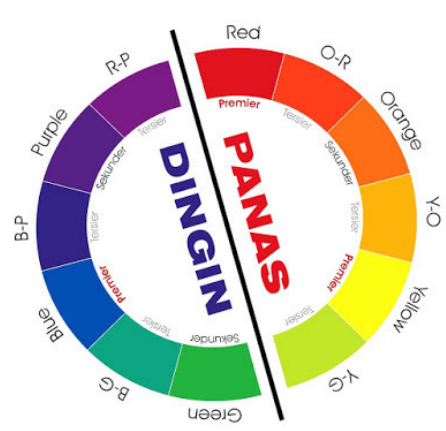

Gambar 5. Pembagian Antara Warna Panas dan Dingin Sumber : (Google, 2016)

(diunduh 13 Mei 2019, pukul 14.30 Wita)

sahabat dengan anak. Pengaplikasian warna pun menjadi salah satu unsur yang sangat diperhatikan pada program ini, secara umum warna yang diaplikasikan adalah warna yang memiliki karakteristik warna dingin. Warna dingin yaitu warna-warna yang mengandung unsur biru dan warna biru itu sendiri, contohnya biru, hijau, ungu kebiruan, hijau tosca, biru muda. Pengaplikasian warna dingin pada ruangan akan memberikan ilusi jarak, akan terasa tenggelam atau mundur. Situasi studio yang tidak terlalu luas pengaplikasian warna dingin dirasa tepat untuk memberikan kesan luas sehingga mempengaruhi emosional anak sebagai pegisi acara pada program tersebut. Warna yang sesuai dengan kepribadian dan kebutuhan bisa mendatangkan bentuk kenyamanan baik fisik, mental, maupun spiritual, disamping itu pula warna bisa menyembuhkan dan menyeimbangkan emosi, sehingga pada akhirnya akan menciptakan keselarasan didalam ruangan.

Warna hijau menjadi warna yang mendominasi pada penataan artistik program Dunia anak. Hijau sendiri memiliki karakteristik warna dingin, dengan makna tumbuhan, natural, lingkungan. Sisi positifnya adalah kesuburan, uang, pertumbuhan, penyembuhan, kesuksesan, natural, harmoni, kejujuran, muda (Luzar, 2011).Warna memiliki pengaruh emosional yang kuat, pengaruh besar terhadap mood, dan mencerminkan ekspresi dari karakter seseorang. Sebagian besar yang terlibat dalam program televisi Dunia Anak adalah anak-anak tingkat dasar, yang mana pada umur ini anak-anak akan sangat mudah terpengaruh emosi atau mood ataupun kreatifitas hanya dengan melihat warna maupun situasi ruangan. Selain warna dingin yang mendominasi tata artistik program Dunia Anak, para penata artistik juga menyisipkan warna hangat sebagai pelengkap, Warna hangat sendiri memberi efek psikologis panas, menggembirakan, menggairahkan dan merangsang (Birren, 1996) Pada pembahasan ini warna hangat disini digunakan sebagai situasi yang menggembirakan, dikarena sebagian besar kegiantan dari program ini adalah menghibur dan tentunya menyenangkan bagi anak-anak sebagai pengisi acara.

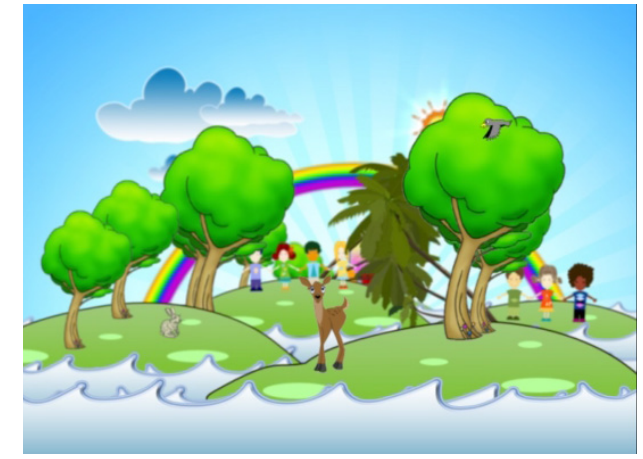

Gambar 6. Bumper Program Dunia Anak TVRI Bali (Sumber : LPP TVRI Bali, thn 2018)

Dapat dilihat dari gambar 1 dan 2, terlihat bahwa warna dingin memang lebih mendominasi sebagai tata artistik program Dunia Anak yang bertujuan memberi kesan luas terhadap ruangan yang sempit, adapun pengaplikasian warna hangat terhadap properti yang bertujuan untuk menstimulasi pandangan anak agar mampu merasakan kegembiraan atau kecerian dalam studio. Menurut penelitian secara umum warna panas akan merangsang anakanak, orang primitif, sederhana dan bersifat ekstrover, sedangkan warna dingin bersifat tenang, introver, dewasa, dan matang (Sulasmi, 2011). Berangkat dari karakteristik warna hijau yang merupakan golongan warna dingin, yaitu tenang, segar, dan tumbuh, warna ini dirasa dapat mewakili kepribadian anak-anak yang sedang dalam masa tumbuh kembang secara mental maupun kreativitasnya, penata artistik untuk program ini penggunaan warna dingin sebagai warna dasar dirasa sangat tepat. Untuk memperjelas makna dari penggunaan warna dingin yang mendominasi warna dalam tata artistik program Dunia Anak TVRI Bali, penulis akan menjelaskan karakteristik warna dingin sehingga dapat digunakan dengan sangat tepat sesuai kebutuhan ruangan.

\section{Ungu}

Ungu merupakan campuran dari warna hangat dan dingin (merah dan biru). Keluarga ungu berkaitan dengan spiritualitas dan imajinasi, hal ini dapat merangsang imajinasi dan mengilhami cita-cita yang tinggi. Warna ungu mewakili masa depan, imajinasi dan mimpi, warna ini berkaitan dengan dunia fantasi (Setyohadi, 2010). Maka dari itu ungu adalah satu golongan warna dingin yang diaplikasikan pada penataan artistik Dunia Anak dirasa tepat mewakili psikis anak-anak yakni imajinasi, fantasi, dan mimpi, sehingga anak-anak yang berada dalam ruangan merasa sedang berada disebuah tempat yang penuh dengan fantasi sesuai dengan imajinasi dari masing-masing anak sebagai pengisi acara pada program tersebut. Warna Ungu diaplikasikan sebagian besar pada properti utama di program Dunia Anak TVRI Bali, seperti properti castil yang merpakan wajah dari program ini. Seiring berjalannya ja- 
man dan teknologi, kini castil buatan yang erupakan wajah dari program Dunia Anak sudah tidak dipergunakan lagi, namun sudah diganti dengan layar LED sebagai wajah baru dari program ini. Meskipun banyak mengalami perubahan, tetapi look dari tata artistik program Dunia Anak tidak berubah dratis, pengaplikasian warna ungu pun digunakan sebagai warna dasar dari gambar LED.

Selain sebagai warna dasar dari LED warna ungu juga diaplikasi pada pilar yang diletakan pada sisi kanan dan kiri LED dengan tujuan mengisi kekosongan ruang yang berada disisi LED. Warna ungu juga digunakan untuk memberikan warna pada lampu set yang diletakan diantara bunga buatan dan dibawah bunga. Fungsi dari lampu berwarna ungu ini adalah memberikan dimensi pada properti 2D, sehingga jika dilihat dari mata kamera akan menjadi lebih berdimensi. Warna ungu juga di aplikasikan pada bunga buatan sebagai properti yang mempercantik set dan menambahkan aksen taman bunga yang ceria dan menyenangkan bagi anak-anak selaku pengisi acara pada program Dunia Anak TVRI Bali.

\section{Biru}

Warna biru merupakan salah satu golongan dari warna dingin, biru dikatakan sebagai warna yang idealis, konservatif, dan predictable. Warna ini merupakan warna yang cocok dipadupadankan dengan warna yang lainnya. Warna biru banyak memberikan kesan keyakinan, kepercayaan, dingin, depresi dan duka berkepanjangan, warna biru banyak ditemui di alam semesta. Warna biru dilambangkan sebagai alam seperti langit dan laut yang memberikan ketenangan, kebebasan dan kehidupan. Warna biru diaplikasikan sebagai warna langit yang cerah, sehingga dapat memberikan kesan tenang, dan kehidupan (Luzar, 2011). Warna biru ini diaplikasikan dominan pada bumper program Dunia Anak TVRI Bali yang mana warna biru ini mewakili gambar langit yang notabene adalah warna biru.

Secara keseluruhan set, warna biru tidak terlalu mendominasi set tata artistik pada ruangan studio, melainkan mendominasi bumper program Dunia Anak. Warna biru diaplikasikan juga pada sisi panggung sebagai dimensi pada panggung atau juga dapat dikatakan sebagai pembatas antara panggung depan dan panggung utama.

\section{Hijau}

Warna ini dihasilkan dari campuran warna biru dan kuning, dan tergolong warna dingin. Hijau biasa dikaitkan dengan alam, warna hijau juga dikaitkan dengan keseimbangan dan keharmonian, dari perspektif psikologi warna, warna hijau merupakan penyeimbang besar hati dan emosi, menciptakan keseimbangan antara kepala dan hati. Warna ini memberikan kesejukan, kemampuan diri untuk menjaga kedamaian dan mampu menampilkan emosi yang positif. Warna ini melambangkan kedekatan alam, menjaga kele- starian dan keseimbangan alam (Luzar, 2011). Inilah yang menjadi alasan warna hijau diaplikasikan pada tata artistik Dunia Anak TVRI Bali dengan tujuan menimbulkan suasana alam atau taman yang diharapkan mampu menstimulasi imajinasi anak-anak seolah-olah mereka sedang berada di taman yang sejuk dan menyenangkan. Warna hijau diaplikasikan pada bumper dan juga pada rumput buatan yang terbuatdari sterofoam sebagai properti penambah aksen taman yang diletakan dibelakang panggung. Terlihat warna hijau jug mendominasi latar background LED yangmencerminakan tanah lapang seperti perbukitn yang berundak. Warna hijau juga terlihat ada pada gambar pohon pada bumper diawal program Dunia Anak TVRI Bali. Tidak saja di set properti, warna hiaju juga diaplikasikan pada wardrobe pengisi acara pada tanggal 1 Juni 2018, yang pada episode ini diisi oleh anak-anak dari SD N 1 Kawan Bangli.

Pengaplikasian warna ungu, hijau dan biru pada tata artistik program Dunia Anak TVRI Bali diharapkan mampu menstimulasi kreatifitas anak-anak, selain bertujuan memberi rasa aman dan nyaman didalam ruangan, warna dingin pun membantu anak-anak dalam fase belajar, yang mana tujuan utama dari program ini adalah bermain sambil belajar, maka setiap unsur dalam penataannya artistiknya harus mendukung setiap aktifitas anak-anak sebagai pengisi acara pada program tersebut. Warna-warna dengan karakteristik warna dingin sanagat membantu menjaga mood anakanak selama proses rekaman berlangsung. Penata artistik program dunia anak bekerja sama menghadirkan ruangan yang bersahabat untuk anak-anak, mengingat kondisi studio yang tidak terlalu luas, maka tim artistik membuat ruangan yang menyenangkan dengan menghadirkan ruangan studioa yang menyenangkan, penuh warna, dan tentunya pemilihan warna yang digemari oleh anak-anak. Sehingga studio yang tidak terlalu luas dapat menjadi ruangan studio yang nyaman bagi anak-anak selaku pengisi acara.

\section{SIMPULAN}

Dari pembahasan di atas, warna dingin dirasa sangat tepat digunakan sebagai warna yang mendominasi sebuah penataan artistik Dunia Anak TVRI Bali yang merupakan sebuah program mengkhususkan untuk anak-anak. Seperti yang diketahui masa anak-anak merupakan masa yang penuh dengan imajinasi, mimpi, tumbuh kembang dan kesegaran/keceriaan. Warna dingin sangat membantu menstabilkan mood anak-anak saat melakukan aktifitas didalam ruangan, sehingga warna dingin adalah warna yang sangat bersahabat dengan anak-anak. Warna dingin yang terapkan pada tata artistik disini disesuaikan dengan kebutuhan tema yang telah disepakati oleh tim produksi Dunia Anak TVRI Bali, sehingga terciptalah sebuah set yang mencerminkan kehidupan anak-anak yang penuh keceriaan. 


\section{DAFTAR RUJUKAN}

Andi, F. (2011). Dasar-Dasar Penyiaran : Sejarah Organisasi, Operasional, dan Regulasi.

Aryawaningrat, H. S. I. K. A. W. I. G. A. A. (2019). ACTUALIZATION OF WOMEN IN DOMESTIC AREAS IN THE GALUH FILM. Capture: Jurnal Seni Media Rekam, 11(1), 46-59. Retrieved from https://jurnal.isi-ska. ac.id/index.php/capture/article/view/2651

Birren, F. (1996). Colour Psychology and Colour Therapy. Ching, F. (1996). Ilustrasi Desain Interior.

Google. (2016). Pengertian Warna Dingin dan Contohnya. Luzar, M. L. C. (2011). Efek Warna Dalam Dunia Desain Dan Periklanan. Humaniora, 2.

Maruta, G. H. S. I. W. S. N. (2019). PEMANFAATAN WARNA PADA POSTER BUKU CERITA BERGAMBAR SEJARAH PURA PULAKI. Desain, 7(1), 71-84. Retrieved from https://journal.lppmunindra.ac.id/index. php/Jurnal_Desain/article/view/3833

Mita Purbasari, R. . D. R. I. K. (2014). Warna Dingin Si Pemberi Nyaman. Humaniora, 5(1), 357-366. Retreived from https://journal.binus.ac.id/index.php/Humaniora/article/view/3034/2423

Setyohadi, B. (2010). Pengaruh Warna Terhadap Kamar Tidur Anak. Teknik Sipil \& Perancangan, 12.

Sriti, M. S. (2004). Peran Warna Interior Terhadap Perkembangan Dan Pendidikan Anak di Taman Kanak-Kanak. Dimensi Interior, 2.

Sulasmi, D. (2011). WARNA: Teori dan Kreativitas Penggunaanya.

Vina. (2016). Tanteku TVRI Bali.

Wirakesuma, I. N. (2017). Eksprsi Wajah Reinterpretasi Visual Di Balik Karakter Dewata Nawa Sanga. Mudra, 32(1), 99-109. Retrieved from https://jurnal.isi-dps.ac.id/ index.php/mudra/article/view/90/41 